\title{
O Direito do Embrião Humano: Mito ou Realidade?
}

\author{
Eduardo de Oliveira Leite*
}

\begin{abstract}
Sumário: Introdução; 1. As diversas concepções de Embrião Humano; 2. O Embrião Humano como pessoa; 3. O Embrião Humano como um amontoado de células; 4. O Embrião como potencialidade de pessoa; 5 . A postura Jurídica; 6. Embriões excedentes e aborto; 7. À Guisa de conclusão.
\end{abstract}

\section{Introdução}

A questão que decidimos abordar não é atual, como se poderia imaginar, mas sempre preocupou o homem na medida em que o mistério da origem da vida no seio da mulher provoca não só curiosidade, mas perplexidade e admiração, ao mesmo tempo que gera problemas comportamentais concretos.

Hoje, porém, mais que no passado, as indagações em torno do embrião humano adquiriram uma atualidade crescente, cada vez mais visível e tangível, dado ao papel que ele passa a representar no interior de nossa sociedade e de nossa cultura: o desenvolvimento inimaginável da medicina e, em particular, da biotecnologia conduz-nos a interrogar sobre sua posição no modo ético-jurídico, a nos questionarmos sobre o estatuto que ele tem - ou deve ter - entre nós.

Se a questão foi, constantemente, invocada, hoje ela se manifesta de maneira infinitamente mais imperativa e urgente, graças ao progresso extraordinário dos conhecimentos e das possibilidades técnicas adquiridas pela humanidade. Basta, para tanto, pensar nas procriações artificiais, e na infinidade de possibilidades daí surgidas, para se poder avaliar a atualidade da problemática.

O embrião humano - fonte e origem da vida - até então escondido no

* Doutor em Direito Privado. Professor titular de Direito Civil. Pesquisador do CNPq e Advogado no Paraná.

Revista da Faculdade de Direito da UFPR, Curitiba, a. 29, n. 29, 1996, p. 121-146 
seio da mulher protegido pelos segredos da natureza que não permitiam o acesso indiscreto da curiosidade humana, passa a ser examinado, estudado e analisado cada vez melhor, desde a concepção, de modo que o "mistério" antigo é revelado com uma precisão técnica que nos permite ver o caminho e o desenvolvimento no organismo materno. Os progressos espetaculares da tecnologia, materializados no aperfeiçoamento de procedimentos quase infalíveis, nos permitem ver o embrião, tocá-lo, avaliá-lo, agindo sobre ele com profundidade inesperada.

$\mathrm{O}$ antes mistério da vida se revela dado técnico e o ventre feminino, envolto em nebulosa, torna-se transparente.

Depois de ter ficado "milênios escondido èm uma espécie de mistério inacessível, o embrião humano tende, de todas as formas, a assumir, no meio da sociedade dos humanos, um lugar novo e original. Um lugar onde, tornando-se visível, tangível e acessível a todos, ele gera toda uma série de novos problemas".

É possível se reconhecer a existência de um estatuto do embrião humano? Caso positivo, que estatuto reconhecer ou atribuir a este embrião humano reduzido, na sua origem, a esta minúscula célula suspensa no seio da mulher ou em um tubo de ensaio, expulsa naturalmente e perdida sem retorno? Como o situar entre nós e no meio de nós?

As questões se sobrepõem ao infinito. E a origem do questionamento parece radicar de duas ordens de razões; de um lado, a curiosidade legítima de saber de onde viemos, o que nós fomos, e como se "farão" os novos homens que nós desejamos no futuro; de outro, as preocupações éticas intensas, preocupados que estamos - diante das possibilidades de ação e de intervenção cada vez mais numerosas que nos oferece a ciência - de discernir entre o bem e o mal, entre aquilo que é razoável, em nome da construção autêntica do Humano, e o que é criticável, porque provoca riscos demais perigosos para a humanidade.

Por isso, nunca uma questão suscitou tanta indagação quanto esta gerada pelo embrião humano, a partir das tentativas desenvolvidas com vistas a contornar a infertilidade.

1 ROLLIN, Francis - Présentation des questions. In: "Colloque du statut de l'embryon humain au sein de la communanté concrète des hommes", p. 10. 
Inicialmente restrita aos meros aspectos médicos e biológicos (de natureza científica, portanto) a questão ganhou todos os terrenos do conhecimento humano e causa perplexidade de natureza antropológica, filosófica, ética e jurídica. Exatamente porque o embrião é humano, e porque da sua viabilidade decorre a viabilidade da espécie humana, em outras palavras, porque ele é humano e se inscreve, quer na sua origem, quer no seu destino, no interior de uma história especificamente humana, o estatuto do embrião humano nunca foi tão debatido, tão questionado e tão contestado como no momento atual.

O que fazer em relação ao embrião humano? Como protegê-lo? Como devemos nos comportar em relação a ele? Como definir, neste terreno, os limites entre justo e injusto, entre o bem e o mal?

Questões graves. Questões difíceis, porque, como se sabe, as respostas apresentadas dependerão diretamente das posições que adotarmos em relação ao estatuto do embrião humano. Ou melhor, revelar-se-ão como conseqüências natural das posturas, inicialmente, assumidas.

\section{As diversas concepções de Embrião Humano}

A problemática criada pelo embrião humano está longe da desejada unanimidade e, ao contrário, se manifesta pela diversidade e pela pluralidade de posições, que levou Jean Carbonnier a visu̧alizar aí uma verdadeira "divisão de consciências", não só entre os diversos segmentos afetados, mas no interior mesmo de cada uma de nossas consciências individuais, na medida em que hesitamos quando se trata de avaliar os argumentos e reconhecemos que não dominamos as respostas com a evidência absoluta que desejaríamos possuir.

Relativamente ao estatuto do embrião humano, três são as posições fundamentais detectáveis na atualidade: duas radicais (ou extremistas) e uma terceira, avançada, que procura o justo equilíbrio nos excessos.

Para uma primeira corrente, o embrião humano deve ser considerado como "pessoa humana", desde o primeiro momento da concepção. A corrente oposta, não visualiza "pessoa" no embrião humano, entendendo que, inicialmente, o embrião nada mais é que um amontoado de células, não possuindo qualquer estatuto de pessoa. A terceira, que se situa entre as duas precedentes, imagina o embrião em termos de "potencialidade", real de

Revista da Faculdade de Direito da UFPR, Curitiba, a. 29, n. 29, 1996, p. 121-146 
"pessoa", destinada a se tornar tal durante seu desenvolvimento progressivo.

\section{O Embrião Humano como pessoa}

Para a teoria concepcionista o embrião humano é, desde o primeiro instante de sua concepção, uma "pessoa humana", inteira, exatamente igual a qualquer outro indivíduo da coletividade.

A teoria concepcionista, que certamente influencia bastante o mundo jurídico, admite ser o embrião, desde a fecundação, algo distinto da mãe e com uma autonomia genética-biológica que não permite estabelecer nenhuma mudança essencial em sua natureza até a idade adulta.

A propósito, é o atendimento que permite aos adeptos desta posição, inserir "ab initio", esta realidade embrionária em uma categoria nítida e bem conhecida: a de "pessoa", que cada um de nós é.

A nível vocabular, os representantes desta corrente se recusam a empregar expressõ̃es do tipo "potencialidade de pessoa" ou "pessoa potencial" (que, precisamente, sugerem a distância e o caminho a percorrer entre o embrião e o homem no qual ele se transformará) para empregar, de forma bastante significativa, a expressão "pessoa" ou "pessoa humana" com um potencial.

É nesta perspectiva que o Código Civil brasileiro fala em nascituro, quando no art. $4^{\circ}$ dispõe que: "A personalidade civil do homem começa do nascimento com vida; mas a lei põe a salvo, desde a concepção os direitos do nåscituro". 2

"Desde a concepção..." logo o embrião humano goza de proteção jurídica desde o início de sua existência (quer seja in utero, quer in vitro). Isto é, o concepto é considerado sujeito de direito reconhecendo-se-lhe caráter de pessoa no exato momento da fecundação.

2 No Brasil são adeptos da corrente concepcionista, Teixeira de Freitas (Consolidação das Leis Civis); Pontes de Miranda (Tratado de Direito Privado, Parte Geral, tomo 1); Rubens Limongi França (Manual de Direito Civil); Anacleto de Faria e André Franco Montoro (Condição Jurídica do Nascituro no Direito Brasileiro); Ives Gandra da Silva Martins (Fundamentos do Direito Natural à Vida - RT 623); Francisco dos Santos Amaral Neto (O Nascituro no Direito Civil Brasileiro. Contribuição do Direito Português - RBDC, vol. 8). e Silmara J. A. Chinelato e Almeida (O Nascituro no Código Civil e o nosso Direito Constituído, In: O Direito de Família e a Constituição de 1.988 - coord. Carlos alberto Bittar). 
Entre o direitos que lhe são reconhecidos se inscreve, certamente, o direito à existência, no sentido de que, assim como ninguém, em nenhuma circunstância, não pode interromper a vida de um indivíduo, da mesma forma e pela mesma razão, ninguém tem o direito de interromper, direta e voluntariamente a vida de um embrião humano, desde sua concepção e desde que ele começou a existir.

A posição é radical e não admite outras interpretações, de forma que, quaisquer que forem as razões invocadas ou as circunstâncias apresentadas, a postura é extremamente clara: a interrupção desta vida é homicídio, passível de reparação penal.

Evidentemente, os adeptos desta posição reprovam todas as formas de fecundaçã́o artificial, já que o recurso artificial à fecundação atinge a dignidade pessoal do embrião. "Dignidade" porque as práticas reduzem o embrião a nível de objeto de uma tecnologia científica, expondo-o à situações inadmissíveis tais como, "ser congelado e conservado no frio", "ser utilizado a fins científicos ou terapêuticos", ou "ser destruído". Todas as possibilidades invocadas atingiriam frontalmente os direitos fundamentais da pessoa humana.

Embora esta postura tenha sido determinadora da posição legislativa do Código Civil (art. $4^{\circ}$ ), acima invocada, e apresente a grande vantagem da clareza e robustez capaz de solucionar todos os problemas práticos encontrados atualmente (aborto, fecundação artificial, experiências, diagnóstico pré-natal, etc...) ela apresenta aspectos frágeis que precisam ser considerados, sob risco de se faltar com a honestidade exigida pela ciência.

A primeira crítica que se pode levantar à concepção é de ordem "científica", ou seja: o fato das primeiras células embrionárias possuírem um patrimônio genético humano é suficiente, por si só, para concluir que elas já constituem uma "pessoa" no sentido mais amplo do termo? Mas não é só. A consistência própria e o papel do "tornar-se embrionário" (de embrião em pessoa humana) são suficientes levados em consideração? Não bastassem estes questionamentos, resta a considerar que o fato de valorizar e direcionar a atenção, quase exclusivamente, sobre o embrião, nos faz esquecer e negligenciar outra categoria de interesses - igualmente verdadeiros e nobres - que são os interesses da mãe e da família, mesmo nos casos trágicos onde ocorre conflito entre uns e outros.

Revista da Faculdade de Direito da UFPR, Curitiba, a: 29, n. 29, 1996, p. 121-146 
A rigidez da postura não abre possibilidade de exceção: ou bem se prioriza o embrião, ou bem, a mãe, ou a família. Ora, o desconhecimento destes conflitos de valores revela-se dificilmente admissível.

\section{O Embrião Humano como um amontoado de células}

Para a teoria genético desenvolvimentista o ser humano passa por uma série de fases: pré-embrião, embrião e feto. O embrião humano, ao menos nos primeiros tempos de sua existência não pode ser reconhecido como uma peșsoa humana, mas sim, um mero "amontoado de células"; células humanas, certamente, mas como são igualmente humanas as células do sangue ou os gametas elaborados pelo organismo humano, uma espécie de material biológico, ainda informe.

Os defensores desta teoria visualizam no embrião um "antes" e um "depois" na aquisição da dignidade humana, o que é difícil de aceitar no mundo jurídico. ${ }^{3}$

Nesse sentido nos encontramos aqui, em posição diametralmente oposta à precedente, pois enquanto naquela há uma lógica de identificação máxima (já que a realidade da criança que vai nascer é projetada, por antecipação sobre a realidade embrionária inicial) nesta ocorre uma lógica de diferenciação máxima entre o embrião e a criança que daí, eventualmente surgirá. Enquanto na primeira, visualiza-se a criança, o ser, através do embrião, nesta o embrião é "coisificado", porque ainda não se tornou uma "pessoa".

As conseqüências, que daí decorrem são contrárias à postura que vê no embrião uma "pessoa". Assim, para a teoria desenvolvimentista é muito difícil aceitar a noção de "direitos do embrião" já que, na qualidade de embrião - isto é, conjunto desorganizado de células - não há pessoa propriamente dita, mas antes, projeto de pessoa, ou massa inerte potencialmente apta a se tornar pessoa.

Como poderia se imaginar que este embrião; ou esta "mórula" que desce, lentamente nas trompas da mulher em direção ao seu útero tem "direitos" capazes de se opor aqueles da mãe ou mesmo contrários aos das pessoas que o cercam?

3 Ver, neste sentido, nosso trabalho, "Procriações artificiais e o Direito", São Paulo, R.T., 1.995. 
Para os desenvolvimentistas antes de se falar em pessoa há uma seqüência de fases ou etapas que, de tão elementares, não geram qualquer possibilidade ou prerrogativa capaz de gerar direitos. Assim, antes da pessoa há o zigoto, mórula, embrião e feto. ${ }^{4}$

Vale lembrar que, para esta corrente, o fato de afirmar a ausência de direitos do embrião não implica em desconhecê-los nenhuma dimensão ética. Ou seja, os desenvolvimentistas estão preocupados com os direitos da "criança a nascer". E se, efetivamente, esta criança deve nascer, esta corrente não aceita qualquer gesto ou ato, durante a gestação, que possa comprometer o futuro humano da criança que é, naturalmente, o termo da longa gestação.

Mas é igualmente em nome desta conviç̧ão dos direitos prioritários da criança a nascer que eles afirmarão, sem vacilar, a legitimidade e o dever moral de interromper um desenvolvimento embrionário que não assegurasse a esta criança a perfeição mínima que se espera para sua sobrevivência e desenvolvimentos normais.

Assim, enquanto a postura concepcionista não aceita, sob qualquer hipótese (mesmo de anomalia congênita) a interrupção da gravidez, priorizando a noção de direito, em detrimento de uma dignidade contestável (qual a dignidade de um monstro, ou de uma criança sem cérebro?) a postura desenvolvimentista favorece o direito da criança a nascer e, por isso, legitima toda e qualquer interferência médica que, atuando sobre o embrião (material biológico ) garante a viabilidade da criança. Nesta ótica, uma vez assegurados os direitos da criança a nascer, as diferentes práticas possíveis, relativas ao embrião, sobre o plano ético, são perfeitamente aceitáveis.

Não é sem razão, que a postura desenvolvimentista (ou genético desenvolvimentista, como pretendem alguns) sempre foi a mais aceita pelo

4 Zigoto (é o óvulo que acaba de ser fecundado por um espermatozóide); mórula (quando no zigoto se processa um certo número de divisões celulares que, através de segmentações sucessivas cria a "mórula"); embrião (quando existe um botão embrionário, isto é, todo o desenvolvimento situado entre o aparecimento do botão embrionário e o término do surgimento de todas as partes do corpo, no final do segundo mês) e, finalmente, feto, da fase antecedente ( $2^{\circ}$ mês $)$ até o parto $\left(9^{\circ}\right.$ mês $)$. 
corpo médico e, igualmente, adotado pelo célebre Relatório Warnock, na Grã-Bretanha.

Embora esta postura seja antagônica à precedente, as críticas que lhe podem ser endereçadas são, praticamente as mesmas, ou seja, tudo gira em torno da questão do discernimento: "Até que momento, nesta hipótese, pode-se considerar o embrião humano como um simples conjunto de células? A partir de que momento deve-se considerar o embrião já próximo do estatuto da pessoa? De acordo com que critérios e definidos por quem? E a partir deste momento, o que fazer? Que comportamentos adotar em relação ao embrião?", são as questões colocadas por Rolin ${ }^{6}$ e que; ainda não foram respondidas, conduzindo-nก̧s, então, à apreciação da terceira postura.

\section{O Embrião como potencialidade de pessoa}

Os representantes desta terceira corrente, embora reconhecendo aspectos de verdade em cada uma das posições anteriores, entendem que elas são insuficientes quando afirmadas isoladamente. Dentro de uma linha eclética, esta tendência procura recompor e completar os pontos que lhes parecem contraditórios naquelas duas posições, sem incorrer nos erros, ou equívocos, que se lhes revelam graves.

Sem classificar o embrião na categoria "humana", nem tampouco negar sua possibilidade de tornar-se "humano", a terceira tendência visualiza no embrião um estatuto específico e irredutível que lhe é próprio. O embrião humano é dotado, desde o primeiro momento de sua existência, de autonomia, mas que não é "humana", como pretende a corrente concepcionista, nem "biológico", como querem os desenvolvimentistas, mas uma autonomia "embrionária".

$\mathrm{Na}$ ótica desta corrente eclética o embrião, enquanto categoria original não pode se confundir nem com a característica humana (que implica na ocorrência de um ser dotado de personalidade), nem com a meramente celular (na medida em que seu desenvolvimento conduz, inexoravelmente, à categoria "humana"). Enquanto embrião, o início da

5 A Comissão Warmock considera embrião o ser que se desenvolve da data da fecundação até o $14^{\circ}$ dia, ou seja, duas semanas. Este prazo, certamente, foi fixado em função de certos imperativos de pesquisa e temendo que as experiências se tornassem impossíveis, se não se admitisse um prazo durante o qual se pudesse agir. Logo, tem uma conotação eminentemente médica.

6

ROLLIN, F. Obra citada, p. 18. 
vida embrionária é "vizinha do nada", mesmo se, efetivamente, esta vida embrionária adquire progressivamente - durante a evolução uterina - um estatuto especificamente humano que o embrião não possui, originalmente.

Por isso, evitando a tendência que consiste em transportar às origens o que só existirá mais tarde (como doutrinam os desenvolvimentistas) os adeptos desta corrente preferem falar de "ser humano potencial", ou de "potencialidade da pessoa", para designar o estatuto específico do embrião.

A corrente favorece enormemente a evolução uterina do embrião, mas não na ótica concepcionista que a encara em bloco, de forma abstrata, entendendo que a identidade "humana se sobrepõe a tudo, desde o início." A evolução constitui uma dimiensão essencial deste ser embrionário que, potencialmente em vias de tornar-se homem (desde o início de sua existência) na origem corresponde ao nada; que só sendo potencialmente viável não é ainda inteiramente o que vai se tornar.

Igualmente contrária à tendência da corrente desenvolvimentista, que vê na capacidade meramente física (biológica) do embrião a capacidade de, através de diversas etapas, tornar-se "ser humano", esta corrente minoriza os aspectos meramente biológicos da evolução e "responsabiliza" igualmente a mãe (num primeiro momento) e o pai (logo em seguida) pelas chamadas "prestações múltiplas" que tanto quanto as biológicas, garantem a plena evolução do embrião.

Estas "prestações múltiplas" que serão fornecidas pela mãe, durante os nove meses da gestação, garantem que a existência do embrião só se desenvolverá sob a condição de ser inteiramente "inscrita" e "envolvida" na própria existência da mãe, "incluída" nela e "carregada" por ela.

Inscrita, envolvida, incluída e carregada pela mãe. Palavras chaves que imprimem uma nova dimensão ao embrião, priorizando o processo de gravidez como determinador da "humanidade" que tanto se procura no embrião e que a lei visualiza como algo imanente no "conjunto de células", "ab initio", quando, na realidade, o caráter "humano" é adquirido pelo doar-se constante da mãe, durante a gravidez.

Nove meses de existências conjuntas e de imanência mútua durante os quais a mãe "faz" este novo ser, tanto quanto ele "se faz" a si próprio.

Aí reside, aos adeptos desta corrente, o papel de responsabilidade específica da mãe, e de forma mais ampla, dos pais, na gênese progressiva 
deste novo ser. E que nos levou a reafirmar, em diversas oportunidades, a necessidade de priorizar, na procriação, o "projeto parental". 7 . Um papel, reafirma-se, que, independente de ser um simples instrumento da natureza, revela-se na plenitude de sua dimensão "pró-criadora", envolvendo pai e mãe quer no aspecto espiritual quanto no corporal.

Papel e responsabilidade "procriadora", no sentido mais intenso da palavra, que não se esgota na mera concepção (como quer a corrente concepcionista), nem na gênese biológica deste novo ser humano (como pretendem) os desenvolvimentistas, mas que se aperfeiçoa no direito e no dever de "gerar" o embrião de forma autenticamente responsável.

Pode-se imaginar o quanto tal concepção valoriza e prioriza o papel dos pais. Não se trata mais de afirmar, como fizeram alguns juristas, que "no colo das mães se forjam os homens de amanhã (como se a responsabilidade materna fosse exclusiva e unilateral) mas sim, de reafirmar que, no útero materno, o amor de pai e mãe decide a existência de um ser em formação.

Frenal já afirmava que "Em oposição à maternidade, que é uma experiência sensorial, a paternidade resulta de um processo de pensamento" (Moisés e o monoteísmo). A paternidade é uma operação mental e sua aquisição é independente do processo de nascimento. O acesso à paternidade (e isto o Direito tem dificuldade de aprender) não se faz através de um registro de nascimento, mas pelo processo de adoção pelo pai do seu próprio filho. Adoção que pode começar muito antes do nascimento. Quando o filho em potencial, ainda é mero embrião. Adoção que se manifesta (concretamente) nas palavras ou nas canções que banham a vida uterina do embrião ou os primeiros tempos de sua vida aérea. Adoção que se expressa no toque (carregado de sensações) do ventre feminino e que para a criança significam "É a tua pequena mão, eu sinto tua cabeça...".

7 Ver, nesse sentido, nosso trabalho "Procriações artificiais e o Direito": “... a criança deve se desenvolver na atmosfera familiar com um pai e uma mãe (..) deseja-se crianças felizes, não se pode pensar em crianças decorrentes de famílias monoparentais, onde, desde o. início, só há um representante, o pai, ou a mãe (...) o interesse de criança impõe seu nascimento num lar, onde existe uma relação heterossexual estável e afetuosa;em conseqüência, a concepção de uma criança por uma mulher ou homem que não participa de tal relação é moralmente e psicologicamente condenável" (p. 140); “Toda a criança tem direito a um pai e a uma mãe (...) É fácil reconhecer nelas uma vocação natural e legítima de ter pai e mãe e, por eles ser educada (p. 150) (...) Se a família que o legislador tem interesse de garantir à criança é formada por pai e mãe, a possibilidade de mulheres solteiras recorrerem à procriação artificial fica excluída" (p. 151). 
Adoção que evita a brutal ruptura da passagem do mundo líquido para o meio aéreo, se existe uma continuidade de informações sensoriais. ${ }^{8}$

O estudo do desenvolvimento dos processos interativos mãe-criança na vida intra-uterina desencadeou toda investigação científica ${ }^{9}$ tendente a valorar este relacionamento.

A partir desta perspectiva, centrada sobre a responsabilidade dos pais, não há mais que se falar em "direitos do embrião", mas, antes de "direitos" específicos, adaptados ao estatuto do ser embrionário.

$\mathrm{O}$ agigantamento da responsabilidade parental nos conduz a encarar diferentemente as situações problemáticas que podem surgir neste terreno: "O que pensar - em uma perspectiva de responsabilidade mútua - de um processo de procriação que se iniciasse contra a vontade profunda da mulher (estupro ou seus equivalentes morais e psicológicos)? $\mathrm{O}$ que fazer se, iniciada uma gravidez, percebe-se que, por uma ou outra razão (risco vital, físico ou psíquico) o custo "risco" é desmesurado para a mãe, ou para a família já constituída? O que fazer se, iniciada a gravidez revela-se claramente que o processo desencadeado não atingirá o resultado esperado (caso de monstruosidade ou de anomalia irreversível)? O que fazer diante de um embrião "in vitro" que, por uma ou outra razão, não se encontra mais inscrito em um projeto parental concreto? Que articulações estabelecer entre a responsabilidade dos pais, a dos médicos e pesquisadores e a sociedade? O fato de um processo embrionário ter começado é suficiente por si próprio e independentemente de qualquer vontade humana - para torná-lo humano e moralmente irresistível? Ele é suficiente para criar a obrigação moral de, custe o que custar, e quaisquer que forem as

8 Querleau demonstrou que os bebês recém nascidos reagem espeçificamente à voz de sua mãe diferenciando-a de outras vozes femininas, e assim agem só recorrendo à condição, como única fonte de informação (Congrès de psycho-pophylaxie obstétricale. Paris, novembro de 1.983). A tese exclui a hipótese de precocidade de um aprendizado neonatal e reforça a hipótese das aquisições pré-natais, ou da ocorrência de uma sensorialidade pré-natal.

9 A título de exemplo citaríamos os trabalhos de MARSHALL H. KLAUS e JOHN H. KENNEL, que centraram suas pesquisas sobre a importância, toda especial, dos primeiros momentos que se seguem ao nascimento (Maternal-Infant Bonding: "The impact of early separation or Loss on family development" - Saint Louis, Mosby, 1.976), de W. S Condon e L. W. Sander, para quem, a palavra da mãe determina e ritma os movimentos do recém nascido ("Neonatal movement is syncronized with adult speech: interactional participation and language acquisition" - Science, 1.974, 183, ,99-101) e ainda o trabalho de A. N. Meltzoff e M. K. Moore, segundo os quais, através de uma metodologia rigorosa, comprovaram que os recém-nascidos, com apenas 12 e 21 dias, são capazes de reproduzir as mímicas feitas pelos seus pais ("Imitation of Facial and Manual Gestures by human Noenates" Science, 19/7, 198, 75-78).

Revista da Faculdade de Direito da UFPR, Curitiba, a. 29, n. 29, 1996, p. 121-146 
conseqüências, levá-lo a seu termo" ${ }^{10}$ São questões que, acertadamente, Rollin levanta em sua indagação.

A responsabilidade mútua dos pais, bem como daqueles que cercam o casal (médicas, pediátricas, etc.) dá condições de levar em consideração diferentes hipóteses da situação trágica na qual eles se encontram, dando-lhes oportunidade de apreciar todos os aspectos do conflito de valores diante do qual eles se encontram. Uma coisa é certa, esta responsabilidade face ao embrião (potencialmente pessoa) permite-lhes adentrar na via de um discernimento ético que não coincide totalmente nem com a inflexibilidade da corrente concepcionista (primeira posição), nem tampouco, com a extrema liberdade da concepção genético desenvolvimentista (segunda posição). Neste sentido é possível afirmar, sem margem de erro, que esta terceira posição dentro de um ecletismo abrrandado, procura o meio termo e evita as soluções radicais.

Esta posição, tanto quanto as demais, suscita igualmente interrogações que geram dúvida e perplexidade.

Assim, como conceituar um estatuto que se situaria a meio caminho do "objeto" e da "pessoa"? A relativa flexibilidade das decisões e dos comportamentos aos quais a posição pode conduzir não corre o risco de abrir brechas nas quais poderiam se lançar os menos bem intencionados provocando toda sorte de abusos graves?

Como decidir entre o "simples material biológico" (conjunto de células) e a "pessoa humana potencial"? O corpo médico escapou deste dilema se apoiando sobre a distinção entre embrião e feto. E, deste dilema se apoiando sobre a distinção entre embrião e feto. E, por isso, o Relatório Warnock, sem vacilar, admite toda e qualquer experiência sobre o embrião até o $14^{\circ}$ dia (conjunto de células) vedando tal possibilidade a partir daquela data.

A idéia, francamente aceita no mundo da ciência médica, não abre margem a qualquer vacilação: durante as duas primeiras semanas, embora possuindo sua identidade genética o embrião não é um indivíduo, logo, não é uma pessoa, no sentido inequívoco do termo. "De outro lado", conclui Lefreve, "a presença da identidade genética revela-se como a de um 'programa', filosoficamente semelhante como a de uma 'potencialidade',

10 ROLLIN, F. Obra citada, p. 20. 
que espera e chama, para passar ao ato (mesmo sob uma forma ainda latente) um desenvolvimento orgânico suficiente". 11

Que há vida, e uma vida organizada, capaz de reprodução (isto é, de divisão celular) todos estão de acordo. O problema continua sendo o de saber a partir de que momento há "estatuto pessoal". É aí que a idéia de gradualidade, ou de potencialidade humana se impõe já que, no início, o que há é um conjunto de células que são ainda totipotentes, mas, certamente, não se trata de um (ser) "ser estruturado", e é apenas, progressivamente, que ele vai adquirir esta "estrutura".

Em que momento pode-se considerar esta "estrutura" suficientemente desenvolvida para que exista - ainda que de maneira latente - pessoa humana? 14 dias respondeu o corpo médico, posição reafirmada por Lefevre nos debates do Colóquio sobre o estatuto do embrião humano: “... nós dispomos de um certo número de dados que nos proíbem - ou, ao menos, nos desaconselham - supor esta 'personalidade' enquanto o zigoto não se tornou um indivíduo. Pois, para que haja 'personalidade' é necessário que, ao menos, nele haja 'individualidade'. Ora, esta última não pode se constituir enquanto os fenômenos gemelares e de fusão embrionária podem ainda ocorrer. Há aí, para mim, uma indicação de ordem negativa, que me impede de pensar que possa aí ocorrer uma 'individualidade' e pois, com mais forte razão, uma pessoa". 12

\section{A postura Jurídica}

A análise das diversas posições a respeito do embrião humano nos conduz a um dilema sem solução: se o embrião não é uma pessoa, mesmo potencial, tudo é permitido e não há nenhuma necessidade da lei se referir ao seu estatuto, assim como redunda ilógico proclamar que ele não é isto ou aquilo. Se, ao contrário, o embrião é uma pessoa, sujeito de direito, nada é possível, a lei mesmo sendo impotente para autorizar o comércio e a destruição do ser humano.

11 LEFEVRE, Charles. Le constituitif de la personne humaine. In: “Colloque du statut de l'embryon humain au sein de la communanté concrète des hommes”, p. 37.

12 LEFEVRE, Charles. Obra citada, p. 55. 
O dilema evoca um conflito de valores entre o interesse médico de um projeto de pesquisa e o respeito de embrião, como "ser", como "pessoa", passível de toda a proteção.

Por isso, a Comissão Warnock, através de uma tendência que Meulders-Klein chamou de "pragmatismo controlado", 13 admitiu que um embrião humano possa ser utilizado como sujeito de pesquisa até o $14^{\circ}$ dia após a fecundação (porque, antes desta data, não há nem elaboração do sistema nervoso, nem inteligência, nem sensações), mas somente sob autorização e vigilância do organismo oficial de controle criado pelo legislador. Fora destas condições, todo emprego do embrião para fins de pesquisa constituiria um delito. O rigorismo inicial previsto pela Comissão não nos deve iludir pois, a própria Comissão acabou admitindo a possibilidade de criação de embriões, especificamente, com vistas à pesquisa e a fecundação entre espécies.

Quando a Comissão assim agiu, abstendo o conceito utilitarista de pré-embrião (da fecundação até o $14^{\circ} \mathrm{dia}$ ) tinha em vista facilitar sobre o mesmo, revelando a ligação entre a qualificação e a utilização. ${ }^{14}$

Apesar da posição bastante clara (e literal) da Grã-Bretanha na delicada matéria, os argumentos que mais se ouvem, como afirma Mémeteau, ${ }^{15}$ são que "nós estamos na presença de seres completos", que "a criança não deve ser tratada como um produto, como um objeto...", que "o essencial é proteger o embrião", que "não se pode dizer que o embrião começa sendo um objeto para se tornar um sujeito".

Ainda que a conclusão nos cause incômodo - e daí decorre a principal razão da acirrada discussão em torno do tema - sempre somos compelidos a concluir que o embrião, desde sua concepção é uma pessoa humana; desde o seu surgimento ele é, potencialmente, um indivíduo, e um dia, se tornará um ser humano completo cujo destino biológico encontra-se inscrito no ADN.

13 MEULDERS-KLEIN, Marie - Thérese. Le droit de l'enfant face ou droit à l'enfant et les pocréations médicalement assistés - In: Revue trismetrielle de Droit Civil, 1.988, p. 661

14 O conceito de "pré-embrião" parece proceder das reflexões do comitê de ética da AMERICAN FERTILITY SOCIETY (sept. 1986,§ 26 s, 45, 53, 56) cf. LABRUSSE - RIOU - "Servitude, servitudes", in: "L'homme, la nature et le droit," C. Bourgois, 1.988, p. 332. Sobre as pesquisas relativas ao pré-embrião ver as recomendações de FIGO, in: Gynécologie internationale, 2/10 déc, $1.993,322 \ldots$ e art. 15 do projeto de Convenção Ética do Conselho da Europa (julho 1.994).

15 MÉMETEAU, Gérard. L'embryon législatif. In: Recueil Dalloz Sirey, 1.994, 44 cahier, p. 361. 
"Quando um espermatozóide humano fecunda um óvulo humano há, certamente, potencialidade de pessoa, mas, sobretudo, surgimento indiscutível de uma vida humana porque este óvulo fecundado não conduzirá a outra coisa, se não, a um ser humano. Esta viḍa, porque ela é humana, é, eminentemente respeitável e deve ser protegida desde o seu começo". 16

Não há como fugir desta evidência incontestável.

As correntes que procuram, num verdadeiro "tour de force" convencer que a "pessoa" se constrói com o passar do tempo, ou com a vida social confundem, e equivocadamente, dois níveis distintos da realidade: a personalidade (que, com efeito, se "constrói") e a pessoa (que existe, ou não existe, mas não pode se "tornar", ou "devenir").

Como apreciou, com aguda sensibilidade Silmara Chinelato e Almeida, "O desenvolvimento do nascituro, em qualquer dos estágios zigoto, mórula, blástula, pré-embrião, embrião e feto - representa apenas um "continum" do mesmo ser que não se modificará depois do nascimento, mas apenas cumprirá as etapas posteriores do desenvolvimento, passando de criança à adolescente, e de adolescente a adulto". ${ }^{17}$

Por isso, quando o Código Civil brasileiro distingue as duas realidades, pessoa e personalidade, deixa bem claro e de maneira precisa, que a "personalidade civil" do homem começa do nascimento com vida, mas que a lei "põe a salvo" (isto é, protege, atribui jurídicidade) desde a concepção os direitos do nascituro. Se a lei atribui direitos ao nascituro "desde a concepção" é porque aí visualizou ocorrência de pessoalidade.

Nascituro é a pessoa por nascer, já concebida no ventre materno (in anima nobile), "a qual são conferidos todos os direitos compatíveis com sua condição especial de estar concebido no ventre materno e ainda não ter sido dado à̀ luz". ${ }^{18}$

Diante desta constatação duas hipóteses restam a examinar já que, ambas, decorrem diretamente da existência do embrião: a relativa aos embriões excedentes e a do aborto.

16 MÉMETEAU, G. Obra citada, p. 362.

17 ALMEIDA, Silmara J. A. Chinelato e. Direitos da personalidade do nascituro. In: Revista do Advogado, Dez/92, nº 38, p. 26.

18 ALMEIDA,Silmara J. A. Chinelato. Obra citada, p. 24. 


\section{Embriões excedentes e aborto}

O processo de fecundação "in vitro" acaba criando, razọ̃es de ordem técnica, mais embriões do que é necessário, para satisfazer os pedidos dos casais estéreis. Chegado o momento de transplantar os embriões na mulher, duas situações podem se apresentar: a) ou há apenas um só embrião apto a ser transplantado; b) ou há diversos embriões disponíveis, o que garante à mulher melhores chances de ficar grávida. A segunda hipótese gera o grave problema dos embriões excedentes, ou "supranumerários". ${ }^{9}$ Como a prática médica tende a não transplantar, simultaneamente, mais de três embriões, para limitar o risco de gravidezes múltiplas, dispõe-se, regularmente, de embriões excedentes. A constatação de que a técnica atual da fecundação "in vitro" produz, necessariamente, a existência de embriões excedentes nos obriga a encarar a questão destes embriões.

Que destino dar a estes embríões? Quando a fecundação "in vitro" é coroada de êxito, o que fazer dos embriões restantes? Guardá-los para uma nova gravidez do mesmo casal? Destruí-los, em nome do respeito que se deve a estas pessoas "potenciais", a estes seres humanos dos quais não se tem mais necessidade? Utilizá-los em proveitos de outros casais estéreis? Servir-se deles para experiências destinadas a fazer progredir a pesquisa sobre o tratamento da esterilidade, as doenças genéticas ou câncer?

Qualquer que for a dificuldade daí decorrente é impossível contornar este problema sem resolvê-lo inicialmente. A partir do momento em que duas células germinais fusionam começa a se desenvolver um processo contínuo - que não mais se presta à definição, sobre bases de um critério científico - de início da vida humana.

Do ponto de vista estritamente ético, em nenhum dos estágios de uma vida "in vitro", o embrião pode ser tratado como uma coisa (como pretendem as legislações mais liberais). Ao contrário, a partir do momento em que duas células se encontram e passam a se multiplicar, quer queiramos ou não, já nos encontramos diante de um novo ser, diante de uma nova vida. É esta vida que a ética pretende proteger; é esta vida que, independente de qualquer consideração meramente científica, o Direito sente vocação e obrigação de proteger.

19 Ver, nesse sentido, nosso trabalho "Procriações artificiais e o Direito", especialmente capítulo I (Aspectos Médicos) e IV (Aspectos éticos). 
"A produção de embriões em número superior às possibilidades médicas ou aos desejos parentais de transplantação com vistas ao nascimento de crianças coloca de forma aguda e imediata o problema da transformação destes embriões e de sua eventual utilização. Esta, pode assumir diversas formas: transplante com vistas a um segundo projeto parental; doação a um outro casal a fim de lhe possibilitar a realização de seu desejo de ter filhos; enfim, utilização para pesquisas". ${ }^{20}$

Se o embrião é um ser humano em formação, ou melhor, um ser vivo em projeto, protegido pelo Direito desde sua concepção, não pode ser tratado como coisa. Daí decorre um primeiro primado ético com intensa repercussão na ordem jurídica: a utilização industrial e comercial dos embriões "in vitro" deve ser terminantemente proibida. A proibição, para surtir efeito, precisa ser prevista em lei e o desrespeito a norma legal deve ser sancionado penalmente.

A utilização de embriões para fins de pesquisa comporta uma dupla resposta: se se trata de pesquisa capaz de provocar progressos do diagnóstico ou da terapêutica, a negativa não pode se impor sob risco de negarmos a evolução da ciência médica; se, ao contrário, os embriões são provocados sem objetivo terapêutico, tal revelar-se-ia contrária à deontologia.

A retirada de embriões de uma mulher fecundada, bem como a fecundação artificial de embriões que não fossem destinados a uma futura implantação com vistas a um nascimento constituíram um atentado à integridade física da paciente e, portanto, sem fim terapêutico, contrárias à ética e ao Direito.

Como um embrião representa, em toda sua expressão, uma pessoa humana potencial, ficariam proibidas todas as experiências suscetíveis de atingir uma modificação artificial do genoma humano ${ }^{21}$ transmissível à descendência, bem como as pesquisas científicas e moralmente condenáveis, como por exemplo, a realização de uma gestação completa "in vitro" (ectogênese), a partenogênese e a produção de organismos anormais. O objetivo desta proibição absoluta não é somente de salvaguardar a espécie

20 De l'éthique au Droit. Etude du Conseil d'Etat, p. 81.

21 Genoma - conjunto dos gens dos cromossomas que contém informações genéticas. $\mathrm{O}$ genoma da espécie humana compreende 23 cromossomas.

Revista da Faculdade de Direito da UFPR, Curitiba, a. 29, n. 29, 1996, p. 121-146 
humana contra práticas que a colocariam em perigo, mas também de proteger um processo de vida contra agressões inaceitáveis.

O não controle destas atividades certamente permitiria o domínio indesejável do processo de reprodução e a aparição da vida, permitiria modificar e manipular os dados desta vida, quer se trate de um indivíduo ou da espécie.

A total permissibilidade - como pretendem alguns cientistas - é inadmissível, pois ela redundaria, apesar dos escrúpulos de consciência de alguns pesquisadores, na idéia que é possível realizar qualquer experiência sobre o embrião, em qualquer condição. Ou seja, o embrião passaria a ser tratado como uma coisa.

Para não incorrer neste equívoco impor-se-ia a necessidade de um efetivo controle, já existente na Europa atualmente, através do regime de autorização concedida por uma Comissão Nacional de Ética. As opiniões emitidas pela Comissão diante de cada caso concreto reafirmariam a finalidade básica do sistema: proteger o indivíduo e a espécie humana. Dentro dessa ótica, todo projeto de pesquisa sobre o embrião deveria ser necessariamente submetido à Comissão Nacional de Ética. Não existiria nenhuma possibilidade de escapar do parecer da Comissão, situando sua pesquisa numa categoria ao invés de outra menos favorável. Toda e qualquer pesquisa seria avaliada e acompanhada por um comitê de ética.

Uma avaliação confiável e permanente seria sempre realizada. Um censo permanente do que se estaria fazendo tornar-se-ia possível e favoreceria o estabelecimento de uma reflexão ética profunda permitindo estabelecer um balanço após determinado tempo.

Se os riscos e abusos excedessem às previsões seria, talvez, necessário estender o campo das proibições parciais ou mesmo se orientar por uma proibição mais ampla.

Não devemos, porém, esquecer, como bem realçou Rubellin-Devichi ${ }^{22}$ que a proibição, pura e simples, de qualquer pesquisa pode gerar inquietude, na medida em que tal proibição pode entravar os progressos científicos de forma não negligenciável.

22 RUBELLIN-DEVICHI, Jacqueline. Les procéations assistées: état des questions. In: Revue Trimestrielle de Droit Civil, 1.987, n³, p. 457 - 497. 
Segundo a jurista francesa: "o fato dos embriões estarem disponíveis de maneira incidente, ou que eles sejam concebidos para a pesquisa, tem pouco importância, pois, nos dois casos, eles não têm nenhuma oportunidade de vida, já que não mais destinados a serem transplantados no útero". A pesquisa, segundo esta jurista, "é indispensável para conhecer os mecanismos da fecundação, a formação de anomalias, e mesmo, para obter informações sobre o câncer, e talvez, até para conhecer as causas dos abortos espontâneos". ${ }^{23}$

É a postura assumida, no Brasil, pela Resolução nº 1358/92 do conselho Federal de Medicina que, relativamente à criopreservação de gametas ou pré-embriões, assim se manifestou:

V. 2. "O número total de pré-embriões produzidos em laboratório será comunicado aos pacientes, para que se decida quantos pré-embriões serão transferidas a fresco, devendo o excedente ser criopreservado, não podendo ser descartado ou destruído.

2. No momento da criopreservação, os cônjuges ou companheiros devem expressar sua vontade, por escrito, quanto ao destino que será dado aos pré-embriões criopreservados, em caso de divórcio, doenças graves ou de falecimento de um deles ou de ambos, e quando desejam doá-los".

Como se depreende da leitura da Resolução num primeiro momento, proíbe-se o descarte e a destruição dos embriões excedentes para, em seguida, atribuir-se ao casal, a prerrogativa de decidir sobre o "destino" dos mesmos. Estranho raciocínio daquele legislador.

Se o direito à integridade física é do nascituro, como ressaltou sem vacilações, Silmara Chinelato e Almeida, e não da mãe, "não é lícito a ela opor-se a tal direito, (...) não cabe à mãe dispor do direito à saúde que não é seu, mas sim, do filho nascituro". 24 Logo, não há que se falar em manifestação de vontade da mãe, ou do casal (como quer a Resolução brasileira). O ovo humano, fecundado ou não "não pertence a ninguém, e também não é propriedade de seus pais; o indivíduo tem o poder de utilizar suas faculdades procriadoras, conforme a natureza lhe permite; é uma liberalidade fundamental do ser humano, de dar ou de não dar a vida. (...)Se os gametas são, no plano jurídico, forças genéticas do indivíduo, eles não

23 RUBELLIN-DEVICHI, J. Obra citada, p. 474.

24 ALMEIDA, Silmara J. A. C. e. Obra citada, p. 27.

Revista da Faculdade de Direito da UFPR, Curitiba, a. 29, n. 29, 1996, p. 121-146 
podem ser objeto nem de uma doação, nem de.uma venda; e eles escapam da vontade individual: o mesmo ocorre com o ovo humano fecundado, quer se trate de uma doação com vistas à pesquisa ou a um outro casal estéril". ${ }^{25}$

A quem caberia, pois, a determinação do destino dos embriões excedentes? Parece-nos que a solução encontrada por Rubellin-Devichi é a mais plausível: na medida em que o casal confia sua sorte, ou a sorte de sua eventual progenitura, à uma equipe científica competente, ele deve confiar nesta equipe. Cabe aos médicos do centro de reprodução decidir o que fazer dos embriões excedentes. Se a equipe considera necessário ouvir a opinião dos pais, esta é uma excelente regra ética que só os honra, mas, tudo indica, que não lhes deve ser imposta. Mesmo porque pareceria estranho, se não cruel, colocar a mãe (ou casal) face à alternativa de destruição, ou da doação, de uma criança já existente e biologicamente do casal. Além disso, pareceria sempre paradoxal considerar que o interesse maior da criança conduzisse a suprimir a existência da mesma (talvez por isso, na seção V, $\mathrm{n}^{\circ} 2$, a Resolução vedou a possibilidade de descarte ou de destruição do embrião).

Quanto à possibilidade de utilizar os embriões excedentes em experiências, as posições se dividem de forma radical e inconciliável. Se o ovo fecundado não é, "ab initio" uma pessoa passível de proteção jurídica (conforme se viu) esta atitude permitiria, sem incoerência, escolher o momento a partir do qual não mais seria possível fazer experiências sobre o embrião, não mais em função do respeito e da dignidade da pessoa humana, mas em função dos sofrimentos que se poderia infligir a um ser vivo. $^{26}$

Os direitos do nascituro são tutelados desde a concepção, logo, o embrião, ainda que "in vitro" também se insere nesta proteção; isto é, o concepto é considerado sujeito de direito reconhecendo-se-lhe caráter de pessoa no exato momento da fecundação.

Mas a questão não é pacífica.

\section{RUBELLIN-DEVICHI, J. Obra citada, p. 476.}

Ver neste sentido, a postura de G. R. Dunstan: "We have to choose. Uterine life must be protected at some point. If we put that point too early, forbidding observation and experimental use of pre-implantation embryos in the early stages of cell division, we shall inhibit much useful research of potential human benefit, including the improvement of the chances of successful pregnancy for lack of which many extra embryos are sacrificed at present". ("The moral status of the human embryo: a tradition recalled", In: Journal of medical ethics, $1.984,1,38-44)$. 
Para as modernas escolas médicas a gravidez iniciar-se-ia com a nidação, ou seja, com a implantação do zigoto (ou ovo) no útero materno. ${ }^{27}$

Contrariamente à tendência rebateu o Prof. Nilson Sant'Anna, no $1^{\circ}$ Congresso Brasileiro de Medicina Legal, com o seguinte argumento: "Então, os dois gametas, as células germinativas do homem e da mulher se fundem e a este ovo resultante dessa fecundação, com esta vida própria, não se pode chamar de humano? Seria então o que ? Inumano? Animal? Vegetal? De que falam então? Que entendem eles quando diferenciam as duas vidas? É a primeira realmente diferente da segunda?"28

A determinação do início da gravidez é fundamental para caracterização do aborto. Para a teoria concepcionista o crime de aborto se configuraria em qualquer fase do desenvolvimento da gravidez, desde a fecundação (e não a partir da nidação do ovo) até o parto. Igualmente ocorreria crime de aborto na destruição dos embriões excedentes da fertilização "in vitro".

Já para a teoria genética desenvolvimentista inexiste crime de aborto na fertilização "in vitro", quer porque o embrião é retirado antes da nidação (portanto, em fase anterior à gravidez, na ótica de seus defensores) quer, porque a gravidez só existe em organismo vivo, não se podendo atribuir tal estado fora dele.

A lei penal brasileira ${ }^{29}$ pune o aborto provocado mas não o define. A doutrina dominante, entretanto, entende haver aborto (etmologicamente: $\mathrm{AB}=$ privação + ORTUS $=$ nascimento) onde ocorre interrupção da gravidez com a morte do concepto. ${ }^{30}$

Com efeito, a gestação é processo que só ocorre em organismo vivo, não podendo ser reconhecida em tubo de ensaio. Levando o raciocínio às

27 Ver, nesse sentido: NAHOUM e BARCELLOS. Placenta. Cordão umbilical. Sistema Amniótico. In: J. Rezende. Obstetrícia, p. 1020; CALANDRA, F. C. e AMARAL, 1. b. d. Obstetrícia, p. 917, entre os penalistas, endossam a mesma posição Celso DELMANTO, Código Penal Comentado, p. 651 e Heleno FRAGOSO, Lições de Direito Penal, vol. I, p. 615.

28 SANT'ANNA. N. de A. Os contraceptivos sob o ponto de vista médico-legal. In: Anais do $1^{\circ}$ Congresso Brasileiro de Medicina Legal, p. 1.823.

29 “Art. 124. Provocar aborto em si mesma ou consentir que outrem lhe provoque". "Art. 125. Provocar aborto sem o consentimento da gestante". "Art. 126. Provocar aborto com o consentimento da gestante".

30 Ver, nesse sentido, Damásio E. de Jesus. Direito Penal, vol. 2, p. 111; Julio Fabrini Mirabete, Manual de Direito Penal, vol. 2 p. 75 e E. Magalhães Noronha, Direito Penal, vol. 2, p. 59.

Revista da Faculdade de Direito da UFPR, Curitiba, a. 29, n. 29, 1996, p. 121-146 
últimas conseqüências, concluir-se-ia que, de acordo com o conceito médico-legal clássico "a destruição voluntária do concepto 'in vitro' não configuraria o delito em questão por ausência de tipicidade, em que pese ficar reconhecido no agente o animus necandi para com o embrião".

Mas, conclui Gonçalves em sua tese, "no tocante à objetividade jurídica do crime de aborto, não se pode recusar, contudo, que o concepto seja (...) pelo menos uma spes personae. Extrai-se destes ensinamentos que se a ocisão voluntária do concepto 'in vitro' não chega a transgredir uma norma jurídica, pelo menos colide frontalmente com a norma social". ${ }^{32}$

Embora Heleno Fragoso entenda que o aborto só ocorre após o início legal da gestação, ou seja, após a nidação do ovo (o aborto é a interrupção do processo fisiológico da gravidez desde a implantação do ovo no útero até o início do parto), ${ }^{33}$ não é este o entendimento dominante na doutrina penalista.

Assim, Nelson Hungria entende que o concepto, como spes personae já pode ser objeto do crime do aborto. Diz o consagrado penalista: "Quem pratica um aborto não opera in materiam brutam, mas contra um homem na ante sala da vida. O concepto é uma pessoa virtual, um cidadão em germe. É um homem in spem. ${ }^{34}$

A posição de Hungria nega, com ênfase, a teoria genético desenvolvimentista na medida em que encara a vida como um fenômeno único, que não comporta gradações, nem fases. Assim sendo, a destruição de um embrião, quer no útero materno, quer fora dele, exatamente porque é vida, importa em destruição de uma vida humana, passível de sanção.

Ouçamos a doutrina penal sobre o aborto.

Para Mirabete, "aborto é a interrupção com a destruição do produto da concepção. É a morte do ovo (até três semanas de gestação), embrião (de três semanas a três meses) ou feto (após três meses) não implicando necessariamente sua expulsão". 35

31 GONÇALVES, N. J. R. Obra citada, p. 65

32 GONÇALVES, N. J. R. Idem, ibidem.

33 FRAGOSO, H. Lições de Direito Penal. Parte Especial, vol. I, p. 615.

34 HUNGRIA, Nelson. Comentários ao Código Penal, vol. 6, p. 499.

35 MIRABETE, J. F. Obra citada, p. 75. 
Afastando qualquer hipótese de que o aborto só ocorreria após a nidação do ovo, o penalista afirma - sem vacilações - que o crime se configura quer em relação ao ovo, quer em relação ao embrião, quer em relação ao feto. Já era esta a posição doutrinária de Magalhães de Noronha, “... aborto é a interrupção da gravidez com destruição do produto da concepção. É a morte do ovo, embrião ou feto". ${ }^{36}$

Não satisfeito em conceituar o aborto, Mirabete, referindo-se à objetividade jurídica, assim se expressa: "Tutela-se nos artigos em estudo a vida humana em formação, a chamada via intra-uterina, uma vez que desde a concepção (fecundação do óvulo) existe um ser em germe, que cresce, se aperfeiçoa, assimila substâncias, tem metabolismo orgânico exclusivo e, ao menos nos últimos meses da gravidez, se movimenta e revela uma atividade cardíaca, executando funções típicas da vida". ${ }^{37}$

Ou seja, desvincula a caracterização do crime à ocorrência de gravidez (nidação do ovo) e reafirma que a tutela do Direito Penal direciona-se à chamada vida intra-uterina, "desde a concepção".

Referindo-se ao tipo objetivo, sem temer a redundância, mas cioso em visualizar a vida como um fenômeno único, reafirma: "O objeto material do delito é o produto da fecundação (ovo, embrião ou feto). Segundo a doutrina, a vida intra-uterina se inicia com a fecundação ou constituição do ovo, ou seja, a concepção". ${ }^{38}$ E conclui: "A morte do produto da concepção pode ocorrer no útero ou fora dele". ${ }^{39}$

A afirmação final do penalista paulista não abre espaço para dúvidas: a destruição de um embrião excedente (fora do útero) também configura crime de aborto. Por isso, é plenamente defensável a conclusão de Nilo Gonçalves: "É incontestável portanto que a ocisão dolosa do concepto, ainda que 'in vitro' representa um ato contra a vida, bem máximo tutelado pelo nosso Código Penal". 40

E porque o embrião constitui uma vida em formação ou elaboração, porque ali existe uma vida em germe - quer a chamemos de vida

36 NORONHA, E. M. Obra citada, p. 59.

37 MIRABETE, J. F. Obra citada, p. 76.

38 MIRABETE, J. F. Obra citada, p. 76.

39 MIRABETE, J. F. Idem, p. 77.

40 GONÇALVES, N. J. R. Obra citada, p. 66.

Revista da Faculdade de Direito da UFPR, Curitiba, a. 29, n. 29, 1996, p. 121-146 
intra-uterina, biológica, fetal ou feto-placental - o Direito Civil põe a salvo os direitos do nascituro e o Direito Penal pune quem a interrompe.

A vida humana "em seu infinito mistério merece respeito, mesmo quando a ordem jurídica se encontra em presença, não apenas de um homem (pessoa) mas de uma spes hominis ${ }^{41}$... Existindo vida intra-uterina, pouco importa a capacidade de o feto atingir a maturação; ele é protegido por ser um embrião de vida humana". 42

A evolução darciência médica, com todos seus lances espetaculares e conquistas inimagináveis, ainda não conseguiu gerar vida. "Não há notícias de que se tenha conseguindo um 'nascimento' em laboratório. A gestação 'in vitro', ao que se sabe, não foi ainda realizada. Embora sem condições de completar seu desenvolvimento, os embriões pertencem à espécie humana e por essa qualidade impõe-se sua proteção". 43

É notório que a supressão do concepto, ainda que "in vitro" como examinamos, representa um ato contra a vida passível de punibilidade. Como se encontra previsto no Código Penal é fundamental a revisão do conceito médico-legal clássico do aborto. Sem esta adaptação da lei às novas situações geradas pela procriação assistida, o atentado contra a vida do concepto "in vitro" "permanecerá a descoberto da lei penal por força do princípio do Direito Romano, que adotamos, de que nullum crime, nulla poena sine praevia lege". 44

Se o embrião pertence à espécie humana e por isso impõe-se sua proteção, como corretamente conclui Barboza, é evidente que, como pessoa em potencial que é, encontra-se fora do comércio. Daí decorre que o direito dos responsáveis legais não lhes atribui poderes absolutos sobre esta "expectativa" de vida humana. Se as partes de um ser humano encontram-se fora do comércio, com muito mais razão todo um ser humano.

41 NORONHA, E. M. Obra citada, p. 61.

42 NORONHA, E. M. Idem, p. 63.

43 BARBOZA, Heloísa Helena. A filiação em face da inseminação artificial e da fertilização "in vitro", p. 82. O referido trabalho, de leitura obrigatória, pelo ineditismo de suas propostas e pela coragem com que apresenta soluções jurídicas até então incogitadas no direito civil pátrio, foi, originariamente, apresentado como tese de concurso para provimento do cargo de professor titular de Direito Civil da Faculdade de Direito da Universidade do Estado do Rio de Janeiro.

GONÇALVES, N. J. R. Obra citada, p. 66. 
A respeito, Heloisa Barboza indaga: "Não nos parece razoável considerar-se o embrião antes da transferência para o útero materno um nascituro. Porém, se negada a sua qualidade de pessoa, como deveremos qualificá-los? Será coisa? Pode ser o embrião, não implantado, objeto de direito? Por todas razões aqui expostas, entendemos não ser possível outra resposta se não a negativa. O embrião, ainda que não transferido, é pessoa, e como tal, mesmo que ainda não investido da capacidade jurídica, não pode ser objeto de direito. Ilícitos, portanto, quaisquer atos que impliquem na sua 'disponibilidade' a qualquer título. Repugna a idéia de serem utilizados em pesquisas, do aproveitamento de suas células e tecidos para transplantes, pior se especialmente 'cultivados' para tanto. Forçoso concluir-se não possam os que geraram o embrião 'autorizar' sua destruição ou seu emprego em pesquisa e experimentações". 45

Nesse sentido, nossa crítica aos artigos $2 .^{\circ}$ e $3 .^{\circ}$ do inciso $\mathrm{V}$ da Resolução 1.358/92 (capítulo IV - Aspectos éticos e seção IV - Doação de óvulos) que nos pareceram contraditórios ou dúbidos. Mesmo que se procurasse interpretar a expressão da vontade dos cônjuges (ou companheiros) como não podendo optar pelo descarte ou destruição ("in fine" do art. $2 .^{\circ}$, do inciso V da Resolução), o "destino" que será dado aos pré-embriões, poderia admitir a utilização dos mesmos em experiências, o que se nos revela inviável na espécie.

Nilo Gonçalves chega a mesma conclusão, " “.. por não poderem dispor da integridade física nem da vida do concepto, não poderão os responsáveis legais, a qualquer pretexto, autorizar a sua destruição ou mesmo cedê-lo para pesquisa ou experimentação". " Igualmente, conclui por ilação o citado autor, “... a simples autorização dos responsáveis legais não é suficiente para que o médico destrua ou utilize seus embriões".

A posição de Nilo Gonçalves reforça nossa tese que os citados artigos insertos na Resolução não resolveram o problema crucial dos embriões excedentes. Se não se admite o descarte, nem a destruição, ou a aplicação em pesquisas ou experimentações, não há que se falar em "expressão da vontade por escrito"; os embriões excedentes só poderão ser doados para satisfação do projeto parental de outro casal estéril.

45 BARBOZA, H. H. Obra citada, p. 83.

46 GONÇ.ALVES, N. J. R. Obra citada, p. 67.

47 GONÇ.ALVES, N. J. R. Obra citada, p. 67.

Revista da Faculdade de Direito da UFPR, Curitiba, a. 29, n. 29, 1996, p. 121-146 


\section{7. À Guisa de conclusão}

O direito essencial que cabe ao Direito e aos homens preservar é o da criança a nascer que, desde sua concepção, isto é, desde a formação do embrião, possui plenamente, em virtualidade ao menos, todos os atributos da pessoa humana.

Por mais que se discuta sobre a exatidão teórica das expressões "pessoa humana potencial", ou "virtual" a realidade do nascituro como entidade própria e inconfundível sempre se impõe: a criança é naturalmente um ser humano desde sua concepção.

Os direitos do embrião humano não dependem nem dos indivíduos, nem do Estado, eles pertencem à natureza humana e são inerentes à pessoa, em razão do ato criador de onde ela tira sua força.

Se nós aceitássemos a idéia que um Estado pudesse dizer hoje que o embrião é um ser humano, sujeito de Direito, forçosamente teríamos que aceitar que outro Estado pudesse dizer amanhã, que não é mais um ser humano, e assim inversamente. E constitucionalmente, nada é menos evidente; humanamente falando, nada é mais temerário, pois, à lógica das definições alternativas do embrião, se juntaria aquela das definições alternativas também do homem em estado vegetativo, do homem deficiente, daquele que se precisa e daquele do qual não mais se tem necessidade.

Ora, a proteção do embrião humano é uma realidade porque corresponde à garantia de um direito fundamental: o direito à vida. "O primeiro e mais importante de todos os direitos fundamentais do ser humano é o direito à vida. É o primeiro dos direitos naturais que o Direito Positivo pode simplesmente reconhecer, mas que não tem a condição de criar". ${ }^{48}$

Ele existe por si só e plana soberano acima dos interesses humanos e das políticas estatais e da ideologia das facções. Como disse Ives Gandra Martins, é um "direito imutável e não circunstancial".

Quando o Estado, através do Direito, protege o direito à vida, está tão somente reconhecendo, no plano jurídico, uma evidência inegável: a permanência e a imutabilidade dos direitos fundamentais e da lei natural. 